\title{
Effectiveness of Psycho-educational Nursing Intervention on Feeling of Burden and Self- Efficacy among Caregivers of Mentally Retarded Children
}

\section{Nagwa Abass Mohamed ${ }^{1}$, Maaly Ibrahim El Malky ${ }^{2}$ and Fathyea Said Sayed ${ }^{3}$}

(1) Master degree in Psychiatric and Mental Health Nursing, Health Technical Institute Imbaba, Egypt. (2) Professor of Psychiatric and Mental Health Nursing, Faculty of Nursing El-Menoufia University, Egypt and (3) Assistant Professor of Psychiatric \& Mental Health Nursing, Faculty of Nursing Benha University, Egypt.

\begin{abstract}
Background: Mental retardation produces psychological, social and financial distress to the whole family. Aim of study: This study aimed to evaluate the effectiveness of psychoeducational nursing intervention on feeling of burden and self-efficacy among caregivers of mentally retarded children. Research design: A quasi-experimental design (pre and posttest) was used to achieve the aim of the study. Setting: This study was conducted at the outpatient clinics for children at the Psychiatric Mental Health Hospital in Benha City, Qalubia Governorate, which is affiliated to General Secretariat of Mental Health in Egypt. Sample: A convenience sample of 40 family caregivers of mental retarded children from the above setting. Tools of data collection: Three tools were used for data collection. I: Structured interview questionnaire was used to collect data about socio demographic characteristic of caregivers and mental retarded children. II: Burden interviewing questionnaire to measure the extent of family caregiver have feeling of burden and III: General self-efficacy scale to assess a general sense of perceived selfefficacy. Results: There was a highly statistically significant improvement in total mean score of feeling of burden and total mean score of self-efficacy post implementation of the program than preprogram. Conclusion: Psycho-educational nursing program had a positive effect on enhancement of feeling of burden and self-efficacy among caregivers of mental retarded children. Recommendations: Psycho educational program should be given to all caregivers of mentally retarded children to reduce their feeling of burden, enhance their self-efficacy and positive optimistic attitude to their mentally retarded children.
\end{abstract}

Key words: Feeling of Burden, Mental Retarded Child, Psycho-educational Nursing Intervention, Self-efficacy

\section{Introduction}

Mental retardation is a life-long disability and has a major impact on the lives of the children and their families. Caring child with mental retardation affects several aspects of caregiver's life negatively including poor physical and emotional state. Mental disabilities are not diseases. Children with mentally retarded have limited mental function, communication skills, ability to maintain themselves and independence of children during the period of developmental and adaptive function, but it is not a disease (Shanti et al., 2018).

Self-efficacy refers to the individuals' different reactions to life stressful experiences and exclusively is applied in care area to describe how the caregivers tackle the ongoing challenges (Azar et al., 2019). Nurses provide care to intellectually disabled children and parents should undertake a variety of distinct roles and act as educators, consultants, advocates and decision makers. 
Determining the family burden of the parents of intellectually disabled children is important for providing professional support to families suffer from burden and for identifying coping behaviors. The families of disabled children will feel that are not alone and will be able to receive professional support for the issues that burden those (Hosny et al., 2020).

The psycho-educational intervention is a set of systematic intervention based on supportive ,handling and upgrading the lives of mentally retarded children depend on the participation, support from families and family needs. The intervention is focused on increasing family knowledge about disease, better adjustment to illness, communication and facilitating problem solving skills (Esther et al., 2018).

\section{Significance of the study}

Mental retardation is a condition of "arrested or incomplete development of the mind" and characterized by impaired developmental skills that contribute to the overall level of intelligence. Nearly 83 million of the world's population is estimated to be mentally challenged, with 41 million having long-term or permanent disability. It ranks fourth in the list of leading causes of disability. The overall prevalence of mentally challenged children is between $1-3 \%$, overall prevalence of mild to severe mentally challenged ranges from 2.5 to 5 per thousand (Rijal, 2013).

In Egypt, Statistics showed that the highest rate of mental retardation was $22.4 \%$, or about 1.6 million. The presence of a mentally handicapped child shakes the family to its foundations. Family experiences a kind of initial shock to stress and reacts with grief, hopelessness, and shame, guilt feelings, feeling of burden and lack of selfefficacy (Mukesh et al., 2015).

\section{Aim of the study}

This study aimed to evaluate the effectiveness of psycho-educational nursing intervention on feeling of burden and selfefficacy among caregivers of mentally retarded children.

\section{Research hypothesis}

The mean score for feeling of burden and self-efficacy among caregiver with mentally retarded children would be improved after implementation of psycho-educational program than before program.

\section{Subject and methods \\ Research design:}

A quasi-experimental design (pre and posttest) was used to achieve the aim of the study.

\section{Setting:}

This study was conducted at the outpatient clinics for children at the Psychiatric Mental Health Hospital in Benha City, Qalubia Governorate, which is affiliated to General Secretariat of Mental Health in Egypt.

\section{Research Subject:}

Sample size:

The estimated sample size was 40 family caregivers

\section{Sample technique:}

A convenience sample was obtained from caregiver of mentally retarded children who meet inclusion criteria. The study will conduct on 40 family caregivers of mentally retard children who receive follow up care in outpatient clinic.

\section{Tools of data collection:}

The data was collected using the following tools:

Tool (1):- A structured Interview Questionnaire which developed by the researcher \& consists of two parts:

Part 1:- Socio-demographic characteristic of caregivers such as age, sex, marital status, level of education, occupation. 
Part II: - Socio-demographic characteristic of mentally retarded children include age, sex, degree and type of mental retardation

Tool (2): Burden interviewing questionnaire:

Modified version of Zarit Burden Interviewing questionnaire (ZBI) developed by Zarit et al., (1986). This tool was used to measure the extent of family caregiver have physical, social and psychological burden as a result of caring their child with mental retarded and modified by Abdel Salam, (2006).

The ZBI questionnaire consisted of 29 items in three main sections:

Physical stress consists of 4 items, social stress consists of 10 items and psychological stress consists of 15 items. 3point likert scale of response for each statement indicates how often the caregiver feels that way: never score (0), sometimes: score (1), always: score (2)

\section{The scale scoring system:}

\section{The burden level was rated}

$* \quad$ From $(0-19)$ mild
$* \quad$ From $(<19>38)$ moderate.
From $(38-58)$ sever.

\section{Tool (3): General self-efficacy Scale:} It was designed by Schwarzer\& Jerusalem, (1995) and translated into Arabic by Radwan, (1997). This scale was created to assess a general sense of perceived self -efficacy, and composed of 10 items.

\section{Rating Scale:}

$1=$ Not at all true.

$2=$ hardly true.

$3=$ moderately true.

$4=$ exactly true

The total score is calculated by finding the sum of the all items. For the general self-efficacy, the total score ranges between 10 and 40, with a higher score indicating more self-efficacy and lower score indicate low self- efficacy.
Reliability of the tool: Test-retest reliability was applied for tool (zarit buirden interviewing questionnaire and General selfefficacy Scale). The tools proved to be strongly reliable $(\mathrm{r} .=0.823$ and 0.799$)$ respectively.

Pilot study:

Before starting data, collection a pilot study was conducted to assess the clarity and applicability of the study tools and identify the time needed to fill each tool. It was carried out on $10 \%$ of the subjects, who were excluded from the main study sample. According to the result of the pilot study necessary modification was done as follow modification of some words in the Arabic form of (zarit Burden interviewing questionnaire) to give the right meaning of the phrase.

\section{Ethical Consideration:}

Before conducting the study the participants were assured about confidentiality and anonymity of their obtained information throughout the study. They were informed about their right to refuse to participate in the study and the right to withdraw from the study at any time. Acceptance of participants who agreed to participate in the study was taken from the participants through a written consent filled by assistance of the patients' rights committee in the hospital.

\section{Field work:}

The psycho-educational nursing program was developed by the researcher after a thorough review of the related literatures and after making the pilot study. The psychoeducational nursing program aimed to improve feeling of burden and self-efficacy among caregivers of mentally retarded children. This program has a set of general objectives and specific objectives for each session. The number of program's sessions was 10 sessions. Based on the results obtained from the assessment tools and review of 
literature, the program content was developed by the researcher in the form of a booklet, which was revised and approved by the supervisors after that the final booklet is distributed for caregivers of mentally retarded children in the first session.

\section{Session of the program focused on:-}

Session 1: Acquaintance session.

Session 2: Overview about mental retarded

Session 3: Overview of feeling of burden

Session 4: Activity of daily living

Session 5: Practice steps to help caregivers to manage problem of elimination to their child

Session 6: How to play with the child and train their child to initiate social interaction

Session 7: Relaxation technique

Session 8: Promote self-esteem

Session 9: Developing skills of solving problem and decision making

Session 10: Summery of the program sessions

\section{Implementation Phase:-}

This phase was beginning by data collection then implementation of psychoeducational nursing program for parent of mentally retarded children who meet previously mentioned criteria.

\section{Data collection (Pre-test):}

Data collection of this study was carried out at outpatient clinic for mental retarded children at the Psychiatric Mental Health Hospital at Benha City, Kaluobia Governorate. The data collection was done on study group (pretest) in first session (acquaintance session) after identify the purpose of the program, describe schedule of the program (number of sessions, time and duration of each session) and outlines the content and steps of the program.

\section{Implementation of the Program:}

- This step focused on the implementation of Psycho-educational Nursing Program for the study group (40 famil caregivers). This group was divided into 8 subgroups; each subgroup composed of 5 caregivers.
- The program consisted of 10 sessions, 3045minute for session's theoretical and 45-60 hours sessions practical. Each subgroup received 10 sessions of psycho-educational nursing program. Sessions was implemented two day per week, usually at Sunday and Thursday every week.

- Researcher work with (8 subgroup, 2days/week). Each subgroup composed of 5 parents, received one session/day /week which lasted for about 30-60 minute and 10 minute for break.

- The program sessions were conducted in the outpatient clinic for children entertainment hall and room for group therapy (includes chairs arranged in 2 raw and table for the equipment).

- To ensure that the parents understand the program contents, each session was started with a summary about what was given through the previous session, and the objectives of the new session were mentioned taking into consideration using simple language to suit all parents. During the session, the researcher used demonstration and modeling by the researcher and one parent to practice skills in psycho-educational nursing program. After that, the researcher used re- demonstration of the skill by each patient to master the skill. After finishing, the researcher thanked the caregivers for participation and encouraged the caregivers for asking about any unclear points.

- Moreover, the researcher made a summary at the end of the session and told the parents about the time of the next session.

\section{Strategies of program implementation:-}

- Methods of teaching: - Open discussion, group discussion, lecture, demonstration, real situation, positive reinforcement, modeling, group cooperation, role play.

- Media: - brochure and video tape.

- Methods of evaluation: - Feedback through oral questions, re-demonstration, 
positive participation, direct observation, role play.

Evaluation Phase (post-test). -This phase aimed to estimate the effect of psychoeducational nursing program on improvement of sense of burden and self-efficacy among parent of mental retarded children. After the conduction of the psycho-educational nursing program sessions for the study group a posttest was done for study group using the pervious assessment tool for data collection (tool two and three for data collection ) to compare the effect of the program pre post intervention .

\section{Statistical analysis:}

The collected data were organized, computerized, tabulated and analyzed by using the Statistical Package for Social Science (SPSS) version 20. Data analysis was accomplished by the use of number, percentage distribution, mean, and standard deviation. Paired t-test was used to compare means within group, and t-test was used to compare two independent means. A significant level value was considered when p- value $=<0.05$.

\section{Results:}

Table (1): Shows that, less than half (47.5\%) of the caregivers aged between $31 \leq 41$ years old the mean age of them $\overline{\mathbf{X}} \pm \mathbf{S D}$ of $38.45 \pm$ 8.81 , three quarter of them $(75.0 \%)$ of them were females, and more than third $(37.5 \%)$ had intermediate education. As regards the marital status, near to three quarter $(67.5 \%)$ of caregivers were married

Table (2): Reveals that there were highly statistically significant enhancement in all subscale levels of feeling of burden among the studied caregiver post program than preprogram $(\mathrm{P} \leq 0.001)$.

Table (3): Illustrates that, there were highly statistically significant relations between levels of feeling of burden among the studied caregivers' and all their sociodemographic characteristics items pre and post program

Table (4): Shows that, there were highly statistically significant relations between the studied caregivers' sense of perceived selfefficacy and their socio-demographic characteristics pre and post program.

Table (5): Indicates that, there were highly statistically significant negative correlations between the studied caregivers' perceived self-efficacy and feeling of burden pre and post program $(\mathrm{P}<0.001)$.

Figure (1): Reveals that, one quarter (25.0\%) of the studied caregivers had mild total feeling of burden preprogram which increased to more than half $(52.5 \%)$ post program. More than third $(32.5 \%)$ of them had moderate total feeling of burden preprogram which decreased to $25.0 \%$ post program, while $42.5 \%$ of them had sever total feeling of burden preprogram which decreased to $22.5 \%$ post program.

Figure (2): Demonstrates that, more than third $(40.0 \%)$ of the studied caregivers had high sense of perceived self-efficacy preprogram which increased to less than two third( $62.5 \%$ )post program, while less than two third $(60.0 \%)$ of them had low sense of perceived self-efficacy preprogram which decreased to ( $37.5 \%$ ) post program. 
Table (1): Socio-demographic characteristics of studied caregivers $(n=40)$.

\begin{tabular}{|c|c|c|}
\hline Socio-demographic characteristics & No. & $\%$ \\
\hline \multicolumn{3}{|l|}{ Age (Years): } \\
\hline $20-30$ & 6 & 15.0 \\
\hline $31-40$ & 19 & 47.5 \\
\hline $41-50$ & 12 & 30.0 \\
\hline $50+$ & 3 & 7.5 \\
\hline \multicolumn{3}{|l|}{$\overline{\mathbf{X}} \pm \mathrm{SD} \quad 38.45 \pm 8.81$} \\
\hline \multicolumn{3}{|l|}{ Gender: } \\
\hline Male & 10 & 25.0 \\
\hline Female & 30 & 75.0 \\
\hline \multicolumn{3}{|l|}{ Educational level: } \\
\hline Don't read and write & 3 & 7.5 \\
\hline Read and write & 7 & 17.5 \\
\hline Intermediate education & 15 & $\mathbf{3 7 . 5}$ \\
\hline University education & 10 & 25.0 \\
\hline Postgraduate studies & 5 & 12.5 \\
\hline \multicolumn{3}{|l|}{ Marital status: } \\
\hline Single & 3 & 7.5 \\
\hline Married & 27 & 67.5 \\
\hline Divorced & 5 & 12.5 \\
\hline Widowed & 2 & 5.0 \\
\hline Separated & 3 & 7.5 \\
\hline \multicolumn{3}{|l|}{ The relationship for the child: } \\
\hline Father & 10 & 25.0 \\
\hline Mother & 27 & 67.5 \\
\hline First degree relatives & 3 & 7.5 \\
\hline \multicolumn{3}{|l|}{ The kinship between the spouses: } \\
\hline Yes & 23 & $\mathbf{5 7 . 5}$ \\
\hline No & 17 & 42.5 \\
\hline \multicolumn{3}{|l|}{ History of mental disorder: } \\
\hline Yes & 15 & 37.5 \\
\hline No & 25 & 62.5 \\
\hline
\end{tabular}


Effectiveness of Psycho-educational Nursing Intervention on Feeling of Burden and SelfEfficacy among Caregivers of Mentally Retarded Children

Table (2): Distribution of feeling of burden subscale levels among the studied caregivers' of mental retardation children pre and post program, $(n=40)$.

\begin{tabular}{|c|c|c|c|c|c|c|}
\hline \multirow{2}{*}{$\begin{array}{l}\text { The caregivers' feeling of } \\
\text { burden subscale levels }\end{array}$} & \multicolumn{2}{|c|}{ Preprogram } & \multicolumn{2}{|c|}{ Post program } & \multicolumn{2}{|c|}{ Significance test } \\
\hline & No. & $\%$ & No. & $\%$ & $\chi^{2}$ & P-value \\
\hline \multicolumn{7}{|l|}{ The physical burden: } \\
\hline Mild & 9 & 22.5 & 20 & 50.0 & \multirow{3}{*}{57.56} & \multirow{3}{*}{$\leq 0.001 * *$} \\
\hline Moderate & 10 & 25.0 & 10 & 25.0 & & \\
\hline Sever & 21 & 52.5 & 10 & 25.0 & & \\
\hline \multicolumn{7}{|l|}{ The social burden: } \\
\hline Mild & 8 & 20.0 & 22 & 55.0 & \multirow{3}{*}{55.28} & \multirow{3}{*}{$\leq 0.001 * *$} \\
\hline Moderate & 8 & 10.0 & 5 & 12.5 & & \\
\hline Sever & 28 & 70.0 & 13 & 32.5 & & \\
\hline \multicolumn{7}{|l|}{ Occupational burden: } \\
\hline Mild & 5 & 12.5 & 19 & 47.5 & \multirow{3}{*}{47.18} & \multirow{3}{*}{$\leq 0.001 * *$} \\
\hline Moderate & 10 & 25.0 & 12 & 30.0 & & \\
\hline Sever & 25 & 62.5 & 9 & 22.5 & & \\
\hline \multicolumn{7}{|l|}{ Relationship with others: } \\
\hline Mild & 7 & 17.5 & 18 & 45.0 & \multirow{3}{*}{44.92} & \multirow{3}{*}{$\leq 0.001 * *$} \\
\hline Moderate & 9 & 22.5 & 15 & 37.5 & & \\
\hline Sever & 24 & 60.0 & 7 & 17.5 & & \\
\hline \multicolumn{7}{|l|}{ Psychological burden: } \\
\hline Mild & 7 & 17.5 & 23 & 57.5 & \multirow{3}{*}{31.61} & \multirow{3}{*}{$\leq 0.001 * *$} \\
\hline Moderate & 14 & 35.0 & 9 & 22.5 & & \\
\hline Sever & 19 & 47.5 & 8 & 20.0 & & \\
\hline
\end{tabular}


Table (3): Relation between socio-demographic characteristics of the studied caregivers' and their feeling of burden pre and post program, $(n=40)$.

\begin{tabular}{|c|c|c|c|c|c|c|c|c|c|c|c|c|}
\hline \multirow{4}{*}{$\begin{array}{r}\text { socio-demographic } \\
\text { characteristics items }\end{array}$} & \multicolumn{12}{|c|}{ Caregiver sense of burden } \\
\hline & \multicolumn{6}{|c|}{ Pre program } & \multicolumn{6}{|c|}{ Post program } \\
\hline & \multicolumn{2}{|r|}{ Mild } & \multicolumn{2}{|c|}{ Moderate } & \multicolumn{2}{|c|}{ Sever } & \multicolumn{2}{|r|}{ Mild } & \multicolumn{2}{|c|}{ Moderate } & \multicolumn{2}{|c|}{ Sever } \\
\hline & No & $\%$ & No. & $\%$ & No. & $\%$ & No. & $\%$ & No. & $\%$ & No. & $\%$ \\
\hline \multicolumn{13}{|l|}{ Age (Years): } \\
\hline $20 \leq 30$ & 3 & 7.5 & 1 & 2.5 & 2 & 5.0 & 4 & 10.0 & 0 & 0.0 & 2 & 5.0 \\
\hline $31 \leq 40$ & 3 & 7.5 & 5 & 12.5 & 11 & 27.5 & 16 & 40.0 & 2 & 5.0 & 1 & 2.5 \\
\hline $41 \leq 50$ & 1 & 2.5 & 3 & 7.5 & 8 & 20.0 & 5 & 12.5 & 3 & 7.5 & 4 & $\begin{array}{l}10 . \\
0\end{array}$ \\
\hline $50+$ & 2 & 5.0 & 1 & 2.5 & 0 & 0.0 & 3 & 7.5 & 0 & 0.0 & 0 & 0.0 \\
\hline Significance test & \multicolumn{3}{|c|}{$X^{2}=18.89$} & \multicolumn{3}{|c|}{ P-value $<0.018 *$} & \multicolumn{3}{|c|}{$\mathrm{X}^{2}=22.73$} & \multicolumn{3}{|c|}{ P-value $<0.001 * *$} \\
\hline \multicolumn{13}{|l|}{ Sex: } \\
\hline Male & 3 & 7.5 & 2 & 5.0 & 5 & 12.5 & 6 & 15.0 & 1 & 2.5 & 3 & 7.5 \\
\hline Female & 6 & 15.0 & 8 & 20.0 & 16 & 40.0 & 22 & 55.0 & 4 & 10.0 & 4 & 10.0 \\
\hline Significance test & \multicolumn{3}{|c|}{$X^{2}=17.86$} & \multicolumn{3}{|c|}{ P-value $<0.001 * *$} & \multicolumn{3}{|c|}{$X^{2}=19.90$} & \multicolumn{3}{|c|}{ P-value $<0.001 * *$} \\
\hline \multicolumn{13}{|l|}{ Educational level: } \\
\hline Don't read and write & 1 & 2.5 & 0 & 0.0 & 2 & 5.0 & 2 & 5.0 & 0 & 0.0 & 1 & 2.5 \\
\hline Read and write & 2 & 5.0 & 1 & 2.5 & 4 & 10.0 & 4 & 10.0 & 1 & 2.5 & 2 & 5.0 \\
\hline $\begin{array}{r}\text { Intermediate } \\
\text { education }\end{array}$ & 4 & 10.0 & 4 & 10.0 & 7 & 17.5 & 11 & 27.5 & 2 & 5.0 & 2 & 5.0 \\
\hline University education & 2 & 5.0 & 2 & 5.0 & 6 & 15.0 & 6 & 15.0 & 2 & 5.0 & 2 & 5.0 \\
\hline Postgraduate studies & 0 & 0.0 & 3 & 7.5 & 2 & 5.0 & 5 & 12.5 & 0 & 0.0 & 0 & 0.0 \\
\hline Significance test & \multicolumn{3}{|c|}{$X^{2}=16.88$} & \multicolumn{3}{|c|}{ P-value $<0.005 * *$} & \multicolumn{3}{|c|}{$X^{2}=18.99$} & \multicolumn{3}{|c|}{ P-value $<0.001 * *$} \\
\hline \multicolumn{13}{|l|}{ Marital status: } \\
\hline Single & 1 & 2.5 & 2 & 5.0 & 0 & 0.0 & 3 & 7.5 & 0 & 0.0 & 0 & 0.0 \\
\hline Married & 6 & 15.0 & 6 & 15.0 & 15 & 37.5 & 19 & 47.5 & 4 & 10.0 & 4 & 10.0 \\
\hline Divorced & 2 & 5.0 & 1 & 2.5 & 2 & 5.0 & 3 & 7.5 & 0 & 0.0 & 2 & 5.0 \\
\hline Widowed & 0 & 0.0 & 0 & 0.0 & 2 & 5.0 & 0 & 0.0 & 1 & 2.5 & 1 & 2.5 \\
\hline Separated & 0 & 0.0 & 1 & 2.5 & 2 & 5.0 & 3 & 7.5 & 0 & 0.0 & 0 & 0.0 \\
\hline Significance test & $\mathbf{X}^{2}=$ & 19.72 & & P-valu & $<0.0$ & $02 * *$ & $X^{2}=1$ & 9.79 & & P-value & $<0.00$ & $01 * *$ \\
\hline The relation for the cl & ild: & & & & & & & & & & & \\
\hline Father & 2 & 5.0 & 0 & 0.0 & 8 & 20.0 & 8 & 20.0 & 1 & 2.5 & 1 & 2.5 \\
\hline Mother & 6 & 15.0 & 9 & 22.5 & 12 & 30.0 & 19 & 47.5 & 3 & 7.5 & 5 & 12.5 \\
\hline $\begin{array}{l}\text { First degree } \\
\text { relationship }\end{array}$ & 1 & 2.5 & 1 & 2.5 & 1 & 2.5 & 1 & 2.5 & 1 & 2.5 & 1 & 2.5 \\
\hline Significance test & $\mathbf{X}^{2}=$ & 17.75 & & P-val & $<0.0$ & $10 * *$ & $X^{2}=1$ & .55 & & P-valt & $<0.0$ & $01 *$ \\
\hline
\end{tabular}


Effectiveness of Psycho-educational Nursing Intervention on Feeling of Burden and SelfEfficacy among Caregivers of Mentally Retarded Children

Table (4): Relation between socio-demographic characteristics of the studied caregivers' and their sense of perceived self-efficacy pre and post program, $(n=40)$.

\begin{tabular}{|c|c|c|c|c|c|c|c|c|}
\hline \multirow{4}{*}{$\begin{array}{c}\text { Caregivers' socio- } \\
\text { demographic } \\
\text { characteristics }\end{array}$} & \multicolumn{8}{|c|}{ Total sense of perceived self-efficacy } \\
\hline & \multicolumn{4}{|c|}{ Pre program } & \multicolumn{4}{|c|}{ Post program } \\
\hline & \multicolumn{2}{|c|}{ High } & \multicolumn{2}{|c|}{ Low } & \multicolumn{2}{|c|}{ High } & \multicolumn{2}{|c|}{ Low } \\
\hline & No. & $\%$ & No. & $\%$ & No. & $\%$ & No. & $\%$ \\
\hline \multicolumn{9}{|c|}{ Age (Years): } \\
\hline $20 \leq 30$ & 5 & 12.5 & 2 & 5.0 & 6 & 15.0 & 1 & 2.5 \\
\hline $31 \leq 40$ & 4 & 10.0 & 14 & 35.0 & 16 & 40.0 & 2 & 5.0 \\
\hline $41 \leq 50$ & 7 & 17.5 & 5 & 12.5 & 7 & 17.5 & 5 & 12.5 \\
\hline $50+$ & 0 & 0.0 & 3 & 7.5 & 2 & 5.0 & 1 & 2.5 \\
\hline Significance test & \multicolumn{2}{|c|}{$\mathrm{X} 2=16.94$} & \multicolumn{2}{|c|}{$\begin{array}{l}\text { P-value }< \\
\text { 0.018* }\end{array}$} & \multicolumn{2}{|c|}{$X^{2}=22.73$} & \multicolumn{2}{|c|}{$\begin{array}{l}\text { P-value < } \\
0.001 * *\end{array}$} \\
\hline & & & & & & & & ender: \\
\hline Male & 4 & 10.0 & 6 & 15.0 & 7 & 17.5 & 3 & 7.5 \\
\hline Female & 12 & 30.0 & 18 & 45.0 & 20 & 50.0 & 10 & 25.0 \\
\hline Significance test & \multicolumn{2}{|c|}{$\mathrm{X} 2=\mathbf{1 5 . 5 7}$} & \multicolumn{2}{|c|}{$\begin{array}{l}\text { P-value }< \\
0.007 *\end{array}$} & \multicolumn{2}{|c|}{$X^{2}=20.90$} & \multicolumn{2}{|c|}{$\begin{array}{l}\text { P-value < } \\
0.001 * *\end{array}$} \\
\hline \multicolumn{9}{|l|}{ Educational level: } \\
\hline Don't read and write & 3 & 7.5 & 0 & 0.0 & 3 & 7.5 & 0 & 0.0 \\
\hline Read and write & 3 & 7.5 & 4 & 10.0 & 5 & 12.5 & 2 & 5.0 \\
\hline Intermediate education & 4 & 10.0 & 11 & 27.5 & 13 & 32.5 & 2 & 5.0 \\
\hline University education & 6 & 15.0 & 4 & 10.0 & 9 & 22.5 & 1 & 2.5 \\
\hline Postgraduate studies & 0 & 0.0 & 5 & 12.5 & 3 & 7.5 & 2 & 5.0 \\
\hline Significance test & \multicolumn{2}{|c|}{$\mathrm{X} 2=13.42$} & \multicolumn{2}{|c|}{$\begin{array}{r}\text { P-value }< \\
0.009 *\end{array}$} & \multicolumn{2}{|c|}{$X^{2}=18.80$} & \multicolumn{2}{|c|}{$\begin{array}{l}\text { P-value < } \\
0.001 * *\end{array}$} \\
\hline \multicolumn{9}{|l|}{ Marital status: } \\
\hline Single & 0 & 0.0 & 3 & 7.5 & 3 & 7.5 & 1 & 2.5 \\
\hline Married & 11 & 27.5 & 16 & 40.0 & 20 & 50.0 & 7 & 17.5 \\
\hline Divorced & 3 & 7.5 & 2 & 5.0 & 4 & 10.0 & 1 & 2.5 \\
\hline Widowed & 2 & 5.0 & 0 & 0.0 & 2 & 5.0 & 0 & 0.0 \\
\hline Separated & 0 & 0.0 & 3 & 7.5 & 2 & 5.0 & 1 & 2.5 \\
\hline Significance test & \multicolumn{2}{|c|}{$\mathrm{X} 2=17.84$} & \multicolumn{2}{|c|}{$\begin{array}{c}\text { P-value < } \\
0.009 * *\end{array}$} & \multicolumn{2}{|c|}{$X^{2}=16.79$} & \multicolumn{2}{|c|}{ P-value $<0.001 * *$} \\
\hline \multicolumn{9}{|l|}{ The relation for the child: } \\
\hline Father & 5 & 12.5 & 5 & 12.5 & 7 & 17.5 & 3 & 7.5 \\
\hline Mother & 10 & 25.0 & 17 & 42.5 & 21 & 52.5 & 6 & 15.0 \\
\hline $\begin{array}{l}\text { First degree } \\
\text { relationship }\end{array}$ & 1 & 2.5 & 2 & 5.0 & 3 & 7.5 & 0 & 0.0 \\
\hline Significance test & $\mathrm{X} 2=$ & 6.73 & & $\begin{array}{l}\text { value }< \\
0.005^{*}\end{array}$ & $X^{2}=1$ & & $\begin{array}{l}\text { P-valt } \\
\text { 0.001: }\end{array}$ & \\
\hline
\end{tabular}


Table (5): Correlation between the studied caregivers' total mean score of perceived selfefficacy and total mean score of feeling of burden pre and post program, $(n=40)$.

\begin{tabular}{||c|c|l|l|c|}
\hline \multirow{2}{*}{ Variables } & \multicolumn{4}{|c|}{ Total sense of perceived self-efficacy } \\
\cline { 2 - 5 } & \multicolumn{2}{|c|}{ Preprogram } & \multicolumn{2}{c|}{ Post program } \\
\cline { 2 - 5 } & \multirow{2}{*}{ R } & P-value & r & P-value \\
\hline \hline Total sense of burden & -0.478 & $0.001 * *$ & -0.699 & $0.001 * *$ \\
\hline
\end{tabular}

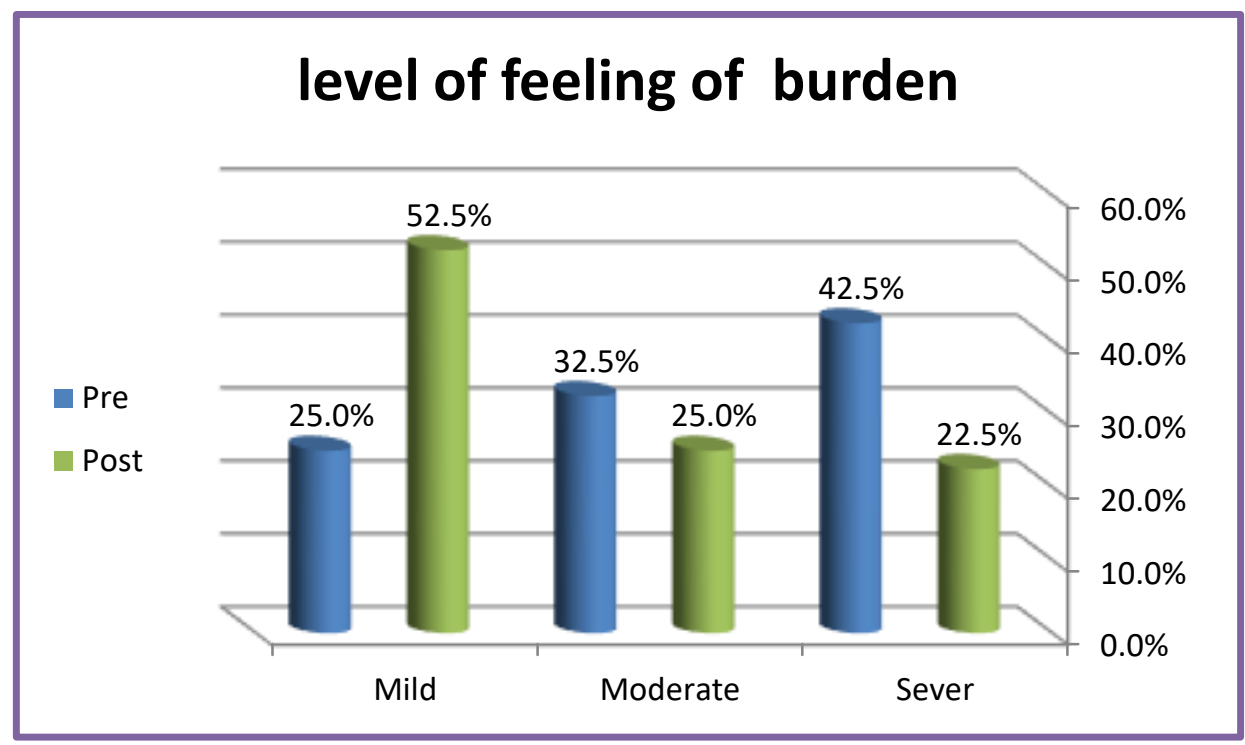

Figure (1): Percentage distribution of the levels of feeling of burden among the studied caregivers' of mental retardation children pre and post program, $(n=40)$.

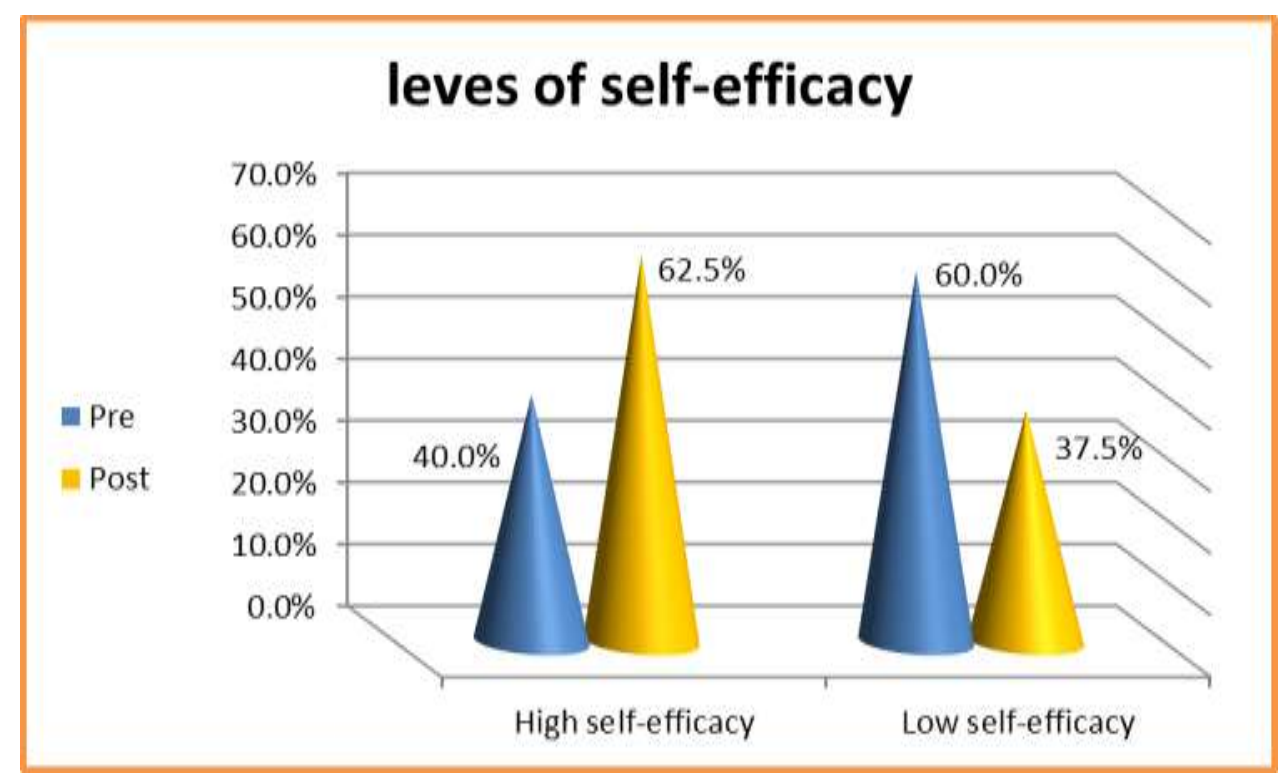

Figure (2): Percentage distribution of the studied caregivers' levels of perceived self-efficacy pre and post program, $(n=40)$ 


\section{Discussion}

Regarding Socio-demographic characteristics of the studied sample: The present study revealed that, less than half of the caregivers aged between $31<-41$ years old the mean age of them $\overline{\mathbf{X}} \pm \mathbf{S D}$ of $38.45 \pm$ 8.81. This finding could be due to delayed age of marriage, failure to find satisfying job, limited financial resources and inability to meet demands of marriage.

This result was consistent with the findings of several research studies as those of ( Maryline \& Flinsi , 2015), who studied assessment the role of parents in the care of mentally challenged children selected special schools who reported that the majority of studied sample were mothers between age of 35 and above. Also (Laimayum et al., 2019) who found that most of parents aged 41-50 years; Also supported by (El-Bilsha, 2019) who stated that around half of his study sample had age less than 35 years.

Regarding subscale feeling of burden among studied sample pre and post program implementation, the current study results indicated that there was a highly statistically significant improvement in the mean score of all subscale of feeling of burden and total mean score of the scale post psycho educational nursing program than pre intervention program. The researcher's point of view was that after program, training sessions may increase the level of parent's awareness and acceptance towards mentally retardation and their children's characteristics, these classes can clarify the emotions and responses which often the parents express and they can decrease families' stress, increase optima parents-child optimal interaction and influence family's health remarkably through teaching strategies. This could be also attributed to the fact that the skills used in the training program are of a comprehensive nature. In addition, improved the parent's level of selfefficacy and enabled him to relieve his negative, painful emotions and feeling of burden in an adaptive manner.

The present results agree with (Kerenhappachu \& Godishala, 2014) who found that mothers of children with mental retardation are experiencing more caregiver's burden and seeking more social support than the mothers of normal children. In the same line (Lohith \& Severine, 2017) who found that caregiver felt that their social status is affected much by taking the child out when compared with a normal child and felt that their life is affected at all with the presence of the mentally retarded child in the family.

The current study reveals that there were highly statistically significant relations between the studied caregivers' total sense of burden and their socio-demographic characteristics at pre and post program preprogram. This result agreement with (ElBilsha, 2019) who found that there is a statistically significant positive correlation among caregivers' burden and their sociodemographic and clinical data. In the same line (Poonguzhali, 2015) who found there was a significant association between the level of burden of caregivers and age, education, marital status and type of family.

The current study revealed that, There were highly statistically significant relations between the studied caregivers' total sense of perceived self-efficacy and their socio-demographic characteristics at pre and post program $(\mathrm{P}<0.001)$. This result agree with Loredana and Massimo (2017) who found that Multiple factors may influence perceived self-efficacy (PSE) such as child temperament qualities, parent individual variables (such as gender, grade of instruction, experienced 
stress, etc.), or family factors (marital support, coparenting, etc.); also,( Azar et al., 2019)found that caregivers' self-efficacy had statistically meaningful relationship with the patient's gender, income potential, housing status and with the caregiver's age, gender, educational level, job, housing status, relationship with the patient, and perceived economic status .

The result of the current study revealed that there were highly statistically significant negative correlations between the studied caregivers' total sense of perceived self-efficacy and total sense of burden pre and post program $(\mathrm{P}<0.001)$. This was supported by Azar et al., (2019) who found that there is a negative and significant correlation between self-efficacy and caregivers' stress or burden with different correlation power according to cultures and diseases also (Sheunget et al., 2013) found that there is negative relationship with positive gains when caregiver selfefficacy was low but a positive relationship when self-efficacy was high; thus, the overall relationship might appear to be near zero.

The current study reveals that, more than third of studied caregiver had moderate total sense of burden preprogram which decreased post program, while less than half of them had sever total sense of burden preprogram which decreased to less than one quarter post program. This is could be due to the effect of psycho-educational intervention which leads to increased awareness about mental retarded and enhanced stress management among the caregivers. In line with the studies carried out by (Huis et al., 2015) who reported that caregivers who received psycho-educational intervention expected a decrease of caregivers' burden. In the same line (Yildirm et al., 2014) found that psycho-education programs are effective in reducing the pressures imposed on the family. In the same line (El-Bilsha, 2019), who found that all caregivers had moderate or severe levels of burden, Moreover, after intervention the level of burden was significantly decreased to around one fifth.

The current study revealed that more than third of the studied caregivers had high total sense of perceived self-efficacy preprogram which increased to less than two third post program. This may be due to the effect of psycho educational nursing program on Caregiver can result in feeling a selfidentity, high levels of self -esteem, decrease worry, or feelings of uncertainty. Caregivers have self-acceptance, feel effective and feel in control of their lives. This result agree with (Loredana and Massimo, , 2017) who found that parent have low of self-efficacy related to stress and caring of children with particular needs, low level of social orienting, and approach to environment.

\section{Conclusions:}

The presence of mentally-retarded children impacts the parents and their family and can be a source of burden for family. Feeling of burden leaded to feeling of failure, dissatisfaction of caregiver's role with their child and in the society, low of self-efficacy, dissatisfaction of quality of life, impaired social interactions. The psycho-educational nursing program had a positive effect on enhancement of self-efficacy and feeling of burden among caregivers with mental rerated children. There was a highly negative significant correlation between feeling of burden of the studied caregiver and their selfefficacy at post intervention of psychoeducational nursing program.

\section{Recommendations:}

- Stress management, assertiveness training and social skill training program should be given to caregivers with mental retarded children to relieve psychological problems and enhance coping patterns.

- Psychological counseling should be integrated as a part of routine nursing intervention for caregivers with mental 
retarded children to enhance their selfefficacy.

- A psycho educational program about Positive thinking about the problem and optimistic attitude by the parents to help the children to grow in a positive way

- Further research on large number of parents about how to cope with their problems effectively.

\section{References:-}

Abdel-Salam, E. (2006). Health education to reduce burden of caregivers for elderly with dementia. MSN unpublished master thesis, faculty of nursing. Menoufiya University.

Azar, R., Mehran, Z., Maedeh, B., Hamideh, A. L. (2019). Relationship between Self-efficacy and Perceived Burden among Schizophrenic Patients' Caregivers January 2019 Journal of Nursing and Midwifery Sciences 6(2):91

El-Bilsha, A. (2019 ) . Effect of family intervention on family caregivers' burden, depression, anxiety and stress among relatives of depressed patients. Middle East Journal of Age and Ageing. 16(1):3-13.

Esther, C., Kerry, R., Manfred, G. (2018). Parent training interventions for parents with intellectual disability, Cochrane Developmental, Psychosocial and Learning Problems Group, 2018 Jul; 2018(7): CD007987.

Hosny, M., Mohamed, A. and Mamdouh, M . (2020). Prevalence and Risk Factors of Intellectual Disabilities in Children, Department of Pediatrics, Al-Azhar University, Assiut, Egypt. The Egyptian Journal of Hospital Medicine (October 2020) Vol. 81 (1), Page 1307-1313.

Huis, V., Verkaik, R., Mistiaen, P., Meijel, B. \& Francke, A.L. (2015). The effectiveness of interventions in supporting selfmanagement of informal caregivers of people with dementia; a systematic meta review. Biomed Central Geriatric journal, 15(1), 147.

Kerenhappachu M.S \& Godishala, S. (2014). Caregiver burden and perceived social support in mother with mental retarded child. International Journal of Scientific and Research Publications, Volume 4, Issue 4, April 2014

Laimayum, N., Mackwin, K., Priyanka,D. (2019). Stress and burden among parents of students in special schools of Mangalore: A cross-sectional study, January 2019 Muller Journal of Medical Sciences and Research 10(2):66

Lohith, S. \& Severine, M. (2017). A study on the problems faced by the parents in handling the mentally challenged children in mangalore district, Sociology Department, Mangalagangothri, Mangalore University, Konaje, Karnataka, India.

Loredana, B. and Massimo, I. (2017). Parental Self-efficacy in Promoting Children Care and Parenting Quality Available from:

Maryline, K . \& Flinsi, Y. (2015). Who study assessment the role of parents in the care of mentally challenged children selected special schools of Tamilnadu.

Mukesh, M., Atul, A., Suneet, D. and Sharma, K. (2015). "Stress \& Coping Strategies in Families of Mentally Retarded Children". Journal of Evolution of Medical and Dental Sciences 2015; Vol. 4, Issue 52, June 29; Page: 8977-8985.

Poonguzhali,S. (2015). Effectiveness of pranayama on stress among mothers of mentally retarded children at selected special school in madurai. College of Nursing,,Madurai Medical College,Madurai

Radwan, S. (1997). Expectations of Efficiency. Faculty of Education, Syria, University of Damascus. Journal of Social Affairs, issue 55, vol 14, pp25-51.

Rijal, A. (2013). Lived-in experiences of mothers with mentally retarded children in 
selected special schools, Bangalore- A Phenomenological approach. Padmashree College of Nursing, Bangalore

Schwarzer, R. and Jerusalem, M. (1995). Generalized Self-Efficacy scale. In J. Weinman, S. Wright, \& psychology: A user's portfolio. Causal and control beliefs (pp. 3537). Windsor, UK: NFER-NELSON

Shanti, R., Iswanto, K., Rifa'i, and Rodiyah, A. (2018). Perception of Family Burden Having Children with Mental Retardation. In Proceedings of the 9th International Nursing Conference (INC 2018), pages 687-690.

Sheung-Tak C., Linda C., Lam, M., Timothy Kwok, Natalie, S. S., BSocSc, Ada, W. T., Fung, (2013). Self-efficacy Is Associated with Less Burden and More Gains from Behavioral Problems of Alzheimer's Disease in Hong Kong Chinese Caregiver .The Gerontologist, Volume 53, Issue 1, February 2013, Pages 71-80.

Yildirim, A., Buzlu, S., Hacıhasanoğlu, R., Camcioğlu, T., Erdiman, S., \& Ekinci, M. (2014). The Effect of Family-to-Family Support Programs Provided for Families of Schizophrenic Patients on Information about Illness, Family Burden and Self-Efficacy. Turkish Journal of Psychiatry, 25(1), 31-7.

Zarit, H., Todd, A. and Zarit, M. (1986). Subjective burden of husband and wives as a cargivers: A longitudinal study. Gerontologist.26, 260 
فاعليه التدخل التمريضي التعليمي النفسي علي الثعور بالعبعو الكفاءه الذاتيه بين مقدمي الرعايه للاطفال ذي الإعاقه الذهنيه باليعا

نجوي عباس محمـ- معالي ابر اهيم المالكي - فتحيه سيد سعيد

الإعاقه الذهنيه هو اضطراب ور اثي يشير إلى قله في مستوى الأداء الذهني العام الذي ينشأ خلال فترة

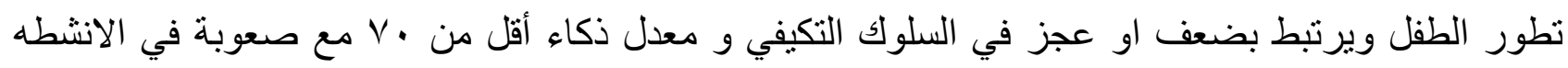

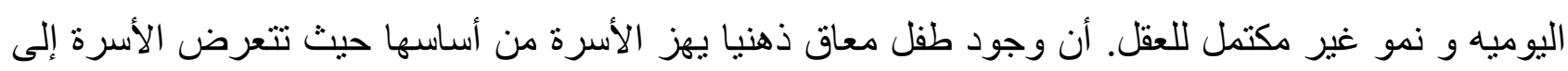

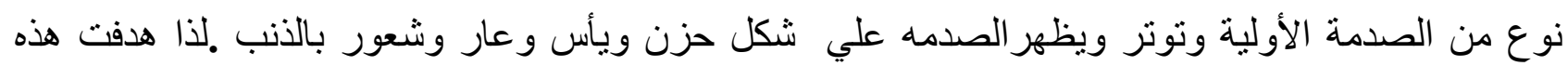
الدراسه إلى تقييم تأثير برنامج تمريضي تعليمي نفسي علي الثعور بالعبه و والكفاءة الذاتية بين مقدمي الرعاية

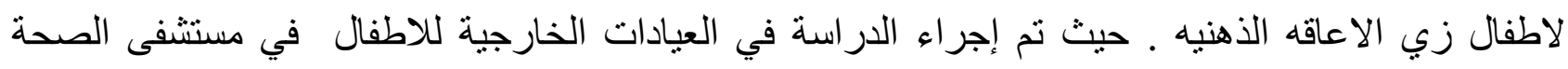

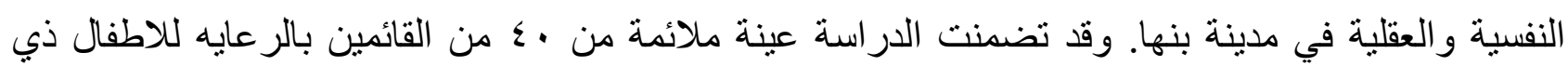

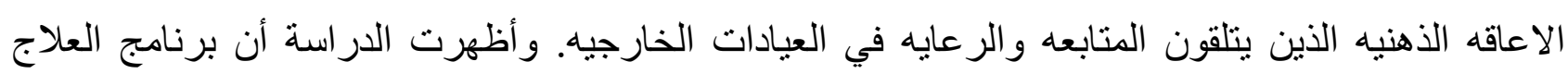

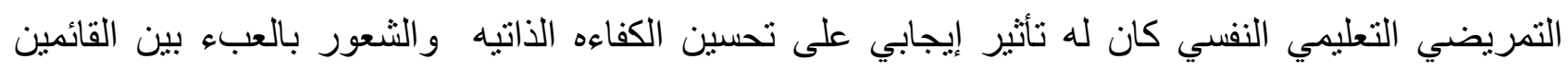

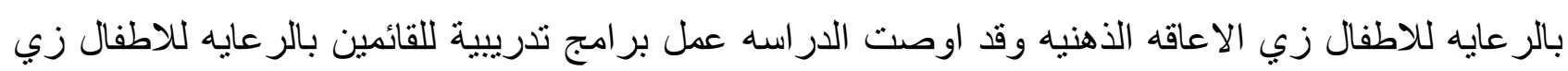

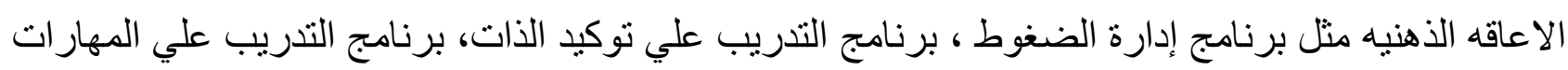
الإجتماعية وذلك لمساعدنهم علي تغلب علي المشاكل النفسية وتعزيز أنماط التكيف لديهم. 